\title{
Bacterial Community Shifts Driven by Nitrogen Pollution in River Sediments of a Highly Urbanized City
}

\author{
Xianbiao Lin ${ }^{1,2,3}$, Dengzhou Gao ${ }^{2}$, Kaijun $\mathrm{Lu}^{4}$ and Xiaofei $\mathrm{Li}^{2,5, *}$ \\ 1 Laboratory of Microbial Ecology and Matter Cycles, School of Marine Sciences, Sun Yat-Sen University, \\ Zhuhai 519082, China; linxb7@mail.sysu.edu.cn \\ 2 School of Geographic Sciences, East China Normal University, Shanghai 200241, China; gaodz0526@163.com \\ 3 Southern Laboratory of Ocean Science and Engineering (Guangdong, Zhuhai), Zhuhai 519000, China \\ 4 The University of Texas at Austin Marine Science Institute, 750 Channel View Drive, Port Aransas, TX 78373, \\ USA; kaijun.lu@utexas.edu \\ 5 Key Laboratory for Humid Subtropical Eco-geographical Processes of the Ministry of Education \& School of \\ Geographical Sciences, Fujian Normal University, Fuzhou 350007, China \\ * Correspondence: lixiaofei198702@126.com; Tel.: +86-591-8346-5214; Fax: +86-591-8346-5397
}

Received: 3 September 2019; Accepted: 2 October 2019; Published: 9 October 2019

check for updates

\begin{abstract}
Effects of nitrogen pollution on bacterial community shifts in river sediments remain barely understood. Here, we investigated the bacterial communities in sediments of urban and suburban rivers in a highly urbanized city, Shanghai. Sediment nitrate $\left(\mathrm{NO}_{3}{ }^{-}\right)$and ammonia $\left(\mathrm{NH}_{4}{ }^{+}\right)$were highly accumulated in urban river. Operation Taxonomic Units (OTUs), Abundance-based Coverage Estimators (ACEs) and Chao 1 estimator in urban rivers were slightly lower than those in suburban rivers, while Shannon and Simpson indices were higher in urban rivers than those in suburban rivers. Proteobacteria, Firmicutes, and Bacteroidetes were the dominant bacterial phylum communities, accounting for $68.5-84.9 \%$ of all communities. In particular, the relative abundances of Firmicutes and Nitrospirae were significantly higher in suburban rivers than in urban rivers, while relative abundances of Bacteroidetes, Verrucomicrobia, and Spirochaetes were significantly lower in suburban rivers than in urban rivers. $\mathrm{NH}_{4}{ }^{+}$was significantly and negatively correlated with abundances of Firmicutes, Nitrospirae, and Actinobacteria. Importantly, the significant and negative effects of sediment $\mathrm{NH}_{4}{ }^{+}$on bacterial richness and diversity suggested that nitrogen pollution likely contribute to the decrease in the bacterial richness and diversity. The results highlight that nitrogen enrichment could drive the shifts of bacterial abundance and diversity in the urban river sediments where are strongly influenced by human activities under the rapid urbanization stress.
\end{abstract}

Keywords: bacterial community; nitrogen pollution; river sediment; urbanization

\section{Introduction}

Global nitrogen pollution is of increasing concern because serious nitrogen pollution has a negative influence on the ecological environment [1,2]. A heavy nitrogen load is one of the pivotal drivers that contributes to water degradation and eutrophication in aquatic environments [3]. Due to the rapidly increasing population in urban areas, urban rivers receive a great amount of anthropogenic nitrogen, such as ammonia $\left(\mathrm{NH}_{4}{ }^{+}\right)$, nitrate $\left(\mathrm{NO}_{3}{ }^{-}\right)$, and nitrite $\left(\mathrm{NO}_{2}{ }^{-}\right)$, which has become an important environmental problem [4]. In addition, urban rivers, as a result of extensive nitrogen input, are considered significant regional nitrous oxide $\left(\mathrm{N}_{2} \mathrm{O}\right)$ source hotspots that contribute to a part of global greenhouse effects [5]. Therefore, studies regarding nitrogen pollution and associated ecological effects have been going on for decades. Numerous studies have documented that urbanization has a great 
influence on nitrogen pollution in urban rivers [6-8]. In urban regions, large amounts of nitrogen from vehicle emission and industrial activity releases can be finally transported into the rivers by surface runoff and sewage discharge $[9,10]$. Importantly, household waste water discharge is also the main source of external $\mathrm{NH}_{4}{ }^{+}$, accounting for roughly $50 \%$ of total nitrogen input in central urban rivers $[9,11]$.

It has been suggested that environmental factors affect microbial richness and diversity in urban rivers ecosystems $[6,10,12,13]$. Zhang et al. [14] reported that total phosphorus, $\mathrm{pH}$, and $\mathrm{NH}_{4}{ }^{+}$ were significant properties affecting microbial community composition. Additionally, Actinobacteria and Betaproteobacteria taxa are strongly correlated with organic carbon, while chemolithoautotrophic bacterial community is highly abundant in the low oxygen environments [15]. It has been suggested that changes in $\mathrm{C} / \mathrm{N}$ ratio and dissolved oxygen (DO) drive the shifts of microbial community composition [16]. High $\mathrm{NH}_{4}{ }^{+}$content is favorable for the Nitrospira, which has also been identified in the urban river sediments [6]. Nitrogen pollution in urban rivers is heavily affected by the rapid urban development [11]. In highly urbanized city, the domestic wastewater discharge is the major source of nitrogen (especially $\mathrm{NH}_{4}{ }^{+}$) in the urban rivers $[9,13]$. A previous study reported that $\mathrm{NH}_{4}{ }^{+}$has a positive effect on Actinobacteria abundance, and $\mathrm{NO}_{3}{ }^{-}$shows a positive correlation with Armatimonadetes, Chloroflexi and Bacteroidetes abundances [14]. In addition, nitrogen transformation pathways in urban rivers have been reported to alter in response to the increasing nitrogen input from anthropogenic activities $[17,18]$, which may be attributed to the shifts of bacterial community $[6,19]$. Although these studies have improved our understanding of the alterations in microbial community composition and nitrogen cycling under nitrogen pollution stress, knowledge of the dynamics of bacterial diversity and abundance in river sediments impacted by large amount of nitrogen inputs is still limited in the highly urbanized areas. Specifically, it has been reported that $\mathrm{NH}_{4}{ }^{+}$is highly accumulated in the sediments, playing an important role of nitrogen source and sink for overlying water $[9,11,14]$. However, the effects of sediment $\mathrm{NH}_{4}{ }^{+}$on the bacterial richness and diversity remain unclear in urban rivers.

The river networks in Shanghai city are highly developed, with a water area of $569.6 \mathrm{~km}^{2}$ crisscrossing this city, accounting for about $9 \%$ of total land areas $\left(6340 \mathrm{~km}^{2}\right)$. With the rapid urbanization of Shanghai city, the river networks have suffered heavy eutrophication and algal blooms due to excessive external nitrogen and phosphorus inputs from household and industrial sewage discharge [5,11]. The water bodies and sediments are black and smelly (Figure S1), which has attracted government attention since the degradation of both water quality and ecological function in urban river systems is attributed to nitrogen pollution. Urbanization has a great influence on nitrogen pollution in the urban rivers because most source of nitrogen derives from human activities [11,13]. The central urban area of Shanghai accounts for $40 \%$ of the total population, contributing to the serious nitrogen pollution in the central urban area [17]. The concentration of nitrogen in river sediments is significantly higher in the central urban area than in suburban areas in Shanghai city $[5,17]$. To date, most previous studies have been concerned with $\mathrm{N}_{2} \mathrm{O}$ emissions and nitrogen load [5,11], and there is limited information on the effect of nitrogen pollution on bacterial dynamics in the river sediments of the highly urbanized city of Shanghai. Therefore, it is necessary to examine the shifts in microbial community induced by the nitrogen pollution in urban rivers, which will contribute to our knowledge of its environmental implications under a rapid urbanization scenario.

Therefore, we investigated the nitrogen pollution and dynamics of bacterial diversity and community structure in the river sediments of highly urbanized city, Shanghai. Thus, the objectives of our study were: (1) to examine whether shifts in the bacterial communities induced by nitrogen load had occurred, (2) to study which variables played a crucial role in shaping bacterial diversity and richness, and (3) to identify that which particular bacterial community was potentially resilient to the serious nitrogen pollution. 


\section{Materials and Methods}

\subsection{Study Area and Samples Collection}

Located in the easternmost region of the Yangtze River Delta of China, Shanghai is the most economically advanced and also the most densely populated city in China. In 2016, the Gross Domestic Product (GDP) and population density of Shanghai were 2817.87 billion RMB and 3816 persons per square kilometer, respectively [20]. Recently, the river networks have suffered serious nitrogen pollution due to the large amount of domestic and industrial wastewater discharge [17]. Nitrogen pollution in the rivers has become the main environmental problem because excess nitrogen load can lead to the degradation of water quality. In this study, the sampling sites were located at central urban area (U1-U6) and suburban area (S1-S6) (Figure 1). Sampling surveys of sediment and overlying water samples were conducted on 10-15 January 2015. At each site, triplicate sediment cores were sampled by a Sediment Sampler (BWT2-04.23.SA, Beeker, Waterland International Co., Ltd., Holland) and the surface sediment sample (0-5 cm depth) was collected. Overlying water was collected by a Ruttner Water Sampler (KC-denmark, Silkeborg, Denmark). Sediment and overlying water samples were stored into sterilized $50 \mathrm{~mL}$ centrifuge tubes and $500 \mathrm{~mL}$ polyethylene bottles, respectively. These samples were placed on ice and transported into laboratory within $4 \mathrm{~h}$. $\mathrm{pH}$ and DO of overlying water were respectively measured by a $\mathrm{pH}$ Meter (Mettler-Toledo, Columbus, OH, USA) and a HQ $40 \mathrm{dm}$ portable water quality analyzer (HACH, Loveland, CO, USA) during the field investigation. Upon return to the laboratory, each sediment sample was homogenized thoroughly under helium and divided into two fractions. The first fraction was stored at $-80{ }^{\circ} \mathrm{C}$ for molecular analyses, and the second fraction was stored at $4{ }^{\circ} \mathrm{C}$ for measurements of sediment properties.

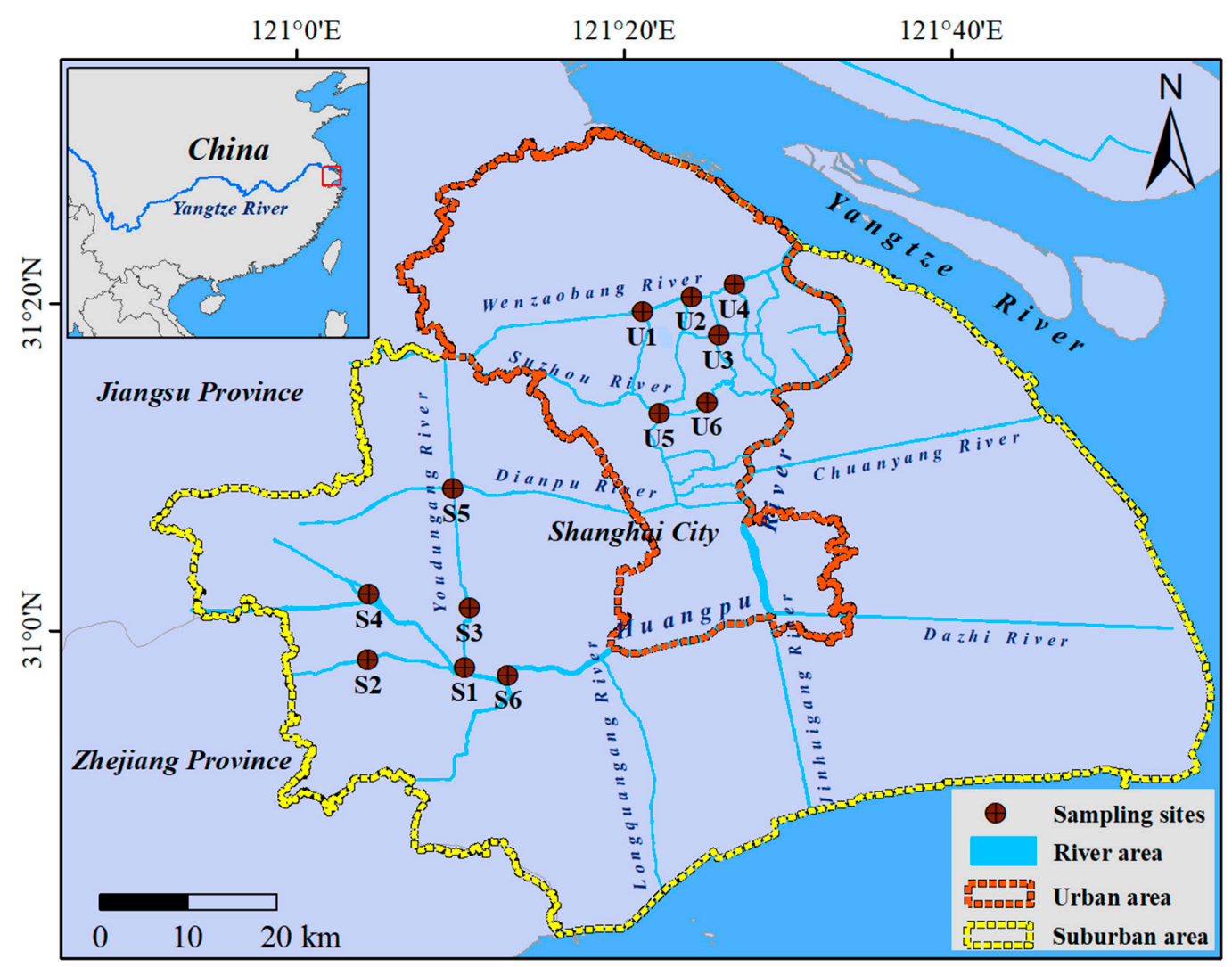

Figure 1. The sampling sites were located at the urban rivers (U1-U6) and suburban rivers (S1-S6) of the highly urbanized city (Shanghai, China). 


\subsection{Analysis of Bottom Water and Sediment Characteristics}

Bottom water samples were filtered through $0.45 \mu \mathrm{m}$ cellulose acetate filters. $\mathrm{NH}_{4}{ }^{+}, \mathrm{NO}_{3}{ }^{-}$and $\mathrm{NO}_{2}{ }^{-}$in bottom water were determined via a continuous-flow nutrient autoanalyzer (SAN plus, Skalar Analytical B.V., Breda, The Netherlands) with detection limits of $0.1 \mu \mathrm{mol} \mathrm{L}{ }^{-1}$ for $\mathrm{NO}_{2}{ }^{-} / \mathrm{NO}_{3}{ }^{-}$and $0.5 \mu \mathrm{mol} \mathrm{L}^{-1}$ for $\mathrm{NH}_{4}{ }^{+}$[21]. Dissolved organic carbon (DOC) in bottom water was measured by a total organic carbon analyzer (TOC-V CPH). Total organic carbon (TOC) and total nitrogen (TN) in sediments were determined using a thermal combustion furnace analyzer (Elementar analyzer vario MaxCNOHS, Frankfurt, Germany). $\mathrm{NH}_{4}{ }^{+}$and $\mathrm{NO}_{3}{ }^{-}$in sediments were extracted with 2 mol L${ }^{-1} \mathrm{KCl}$ solution at the speed of $250 \mathrm{r} \mathrm{min}^{-1}$ shaking for $60 \mathrm{~min}$ and measured using a nutrient autoanalyzer [21]. Sulfide in sediment was determined by the method of methylene blue spectrophotometry. Ferrous oxides (Fe(II)) in sediment was extracted by $10 \mathrm{~mL} 0.5 \mathrm{~mol} \mathrm{~L}^{-1} \mathrm{HCl}$, and measured using the ferrozine method [22].

\subsection{DNA Extraction, Amplification and $16 S \mathrm{r}$ RNA Gene-Based Pyrosequencing}

DNA in sediment was extracted from $0.25 \mathrm{~g}$ fresh sediment using Power Soil DNA Isolation Kits (MOBIO, Carlsbad, CA, USA) according to the manufacturer's protocols. Purity and content of DNA were measured using a Nanodrop-2000 Spectrophotometer (Thermo Fisher Scientific, Waltham, MA, USA). The V4 hypervariable region of bacterial 16S rRNA gene was amplified using the primers F515 (5'-GTGCCAGCMGCCGCGGTAA-3') and R806 (5'-GGACTACHVGGGTWTCTAAT-3'). Amplification of polymerase chain reaction (PCR) were performed in $25 \mu \mathrm{L}$ reaction mixtures including $1.0 \mu \mathrm{L}$ of each primer $(10 \mu \mathrm{M}), 1 \mu \mathrm{L}$ of template DNA, $12.5 \mu \mathrm{L}$ of Taq PCR Master Mix $(2 \times$, with blue dye), and $9.5 \mu \mathrm{L}$ of sterile distilled water. The thermos cycling was conducted in the condition of $98^{\circ} \mathrm{C}$ for $1 \mathrm{~min}$ followed by 35 cycles of $10 \mathrm{~s}$ at $98{ }^{\circ} \mathrm{C}, 30 \mathrm{~s}$ at $50{ }^{\circ} \mathrm{C}, 30 \mathrm{~s}$ at $72{ }^{\circ} \mathrm{C}$, and a final 5 min extension cycle at $72^{\circ} \mathrm{C}$. PCR amplicons were purified using Agarose Gel DNA Purification Kit (TaKaRa Biotechnology, Dalian, China) and quantified using a Quant-It Pico Green kit (Invitrogen, Carlsbad, CA, USA) with a Qubit fluorometer (Life Technologies, Carlsbad, CA USA). Subsequently, the purified amplicons were submitted to Novogene Beijing for Illumina paired-end (PE) library preparation, cluster generation and $250 \mathrm{bp}$ PE sequencing on an Illumina MiSeq machine.

\subsection{Processing of Sequence Data}

In this study, the raw sequence data was analyzed with Quantitative Insights into Microbial Ecology (QIIME) toolkit (version 1.9.0, http://bio.cug.edu.cn/qiime/). Raw FASTQ files were de-multiplexed with QIIME, and the paired reads were joined with FLASH (fast length adjustment of short reads) using default setting [23]. Sequences with low quality reads, unknown nucleotides and ambiguous reads and trimming off the barcodes and primers were removed from the dataset, and were subsequently used for the following analysis. The joined pairs were then filtered and analyzed with QIIME. Shannon diversity index [24] and Chao1 estimator [25] were calculated using the software MOTHUR. Sequences were clustered into operational taxonomic units (OTUs) based on $97 \%$ sequence identity by using the average neighbor algorithm. Rarefaction curves were drawn to compare OTU-based bacterial diversity among the measured samples of studied sites. The differences in bacterial community structure between urban rivers and suburban rivers were analyzed using a phylogeny-based weighted UniFrac distance metric. Heat map of dominated bacterial community composition at the genus level was drawn using R software (version 3.2.3, Lincoln, NE, USA). In addition, the abundance-based coverage estimators (ACE), and Simpson diversity indices of bacterial communities were calculated using MOTHUR software (version 1.22.2, The University of Michigan, Ann Arbor, MI, USA).

\subsection{Statistical Analysis}

Statistical analyses of this study were performed using SPSS (version 19.0, SPSS Inc., Chicago, IL, USA), and $p<0.05$ values were considered to be significant. A one-way analysis of variance (ANOVA) 
with Tukey's HSD test was conducted. The significant differences in bacterial richness and diversity between urban and suburban rivers were identified by the independent sample analysis with $t$-test. Pearson's correlation analysis was also performed to explore the relationships of relative bacterial abundance and diversity indices and sediment and water variables. The overall difference in bacterial community structure was identified by nonmetric multidimensional scaling (NMDS) with weighted UniFrac NMDS plots. The difference of bacterial structure was identified using analysis of similarity (ANOSIM). Redundancy analysis (RDA) combined with Monte Carlo test (999 permutations) was performed to elucidate the relationships between bacterial richness and diversity and environmental variables using CANOCO software (version 4.5, Wageningen, The Netherlands).

\section{Results}

\subsection{Chemical Characteristics of Overlying Water and Sediment}

The chemical properties for sediments and overlying water are given in Table 1 . The $\mathrm{pH}$ for overlying water ranged from 6.8 to 7.1 in urban rivers and from 7.2 to 7.6 in suburban rivers. DO in overlying water varied between 1.15 and $4.92 \mathrm{mg} \mathrm{L}^{-1}$, and DO was slightly lower in urban rivers than in suburban rivers. The contents of DOC in overlying water were 7.2-21.8 $\mathrm{mg} \mathrm{C} \mathrm{L}^{-1}$ and $5.8-19.6 \mathrm{mg} \mathrm{C} \mathrm{L}^{-1}$ in urban rivers and suburban rivers, respectively. The contents of $\mathrm{NO}_{3}{ }^{-}$and $\mathrm{NO}_{2}{ }^{-}$in overlying water varied between 2.64 and $9.06 \mathrm{mg} \mathrm{N} \mathrm{L}^{-1}$, and between 1.89 and $197 \mu \mathrm{g} \mathrm{N} \mathrm{L}^{-1}$, respectively. However, $\mathrm{NH}_{4}{ }^{+}$in overlying water varied spatially among the sample sites, with contents of $6.43-13.7 \mathrm{mg}$ $\mathrm{N} \mathrm{L}^{-1}$ in urban rivers and $0.01-0.24 \mathrm{mg} \mathrm{N} \mathrm{L}^{-1}$ in suburban rivers. $\mathrm{NH}_{4}{ }^{+}$in overlying water was significantly higher in urban rivers than in suburban rivers ( $t$-test, $p<0.05$, Table 1 ). Sediment sulfide was significantly higher in suburban rivers than in urban rivers ( $t$-test, $p<0.05)$. Contents of sediment TOC and TN were $10.8-33.2 \mathrm{mg} \mathrm{C} \mathrm{g}^{-1}$ and $1.35-3.26 \mathrm{mg} \mathrm{N} \mathrm{g}^{-1}$, respectively. The contents of $\mathrm{NO}_{3}{ }^{-}$and $\mathrm{NH}_{4}{ }^{+}$in sediment ranged from 0.32 to $3.25 \mu \mathrm{g} \mathrm{N} \mathrm{g}{ }^{-1}$ and from 4.79 to $240 \mu \mathrm{g} \mathrm{N} \mathrm{g}{ }^{-1}$, and the contents were significantly higher in urban rivers than in suburban rivers $(p<0.05$, Table 1 , Figure S2). Sediment $\mathrm{Fe}(\mathrm{II})$ ranged from 7.89 to $15.4 \mathrm{mg} \mathrm{Fe} \mathrm{g}^{-1}$ in urban rivers and from 0.43 to $25.1 \mathrm{mg} \mathrm{Fe} \mathrm{g}^{-1}$ in suburban rivers. Contents of $\mathrm{NH}_{4}{ }^{+}$in overlying water and sediments were significantly higher in urban rivers than in suburban rivers ( $t$-test, $p<0.05$, Table 1$)$.

\subsection{Bacterial Richness and Diversity Indexes}

In this study, the 16S rRNA gene sequences ranged from 76,364 to 91,891 for each sample, with a total of 120,365 sequences from the 12 samples. The bacterial richness and diversity indexes were given in Table 2. The sequences were grouped into 51,505 OTUs based on $97 \%$ similarity. 3870-4762 OTUs of individual sample were observed, contributing to $7.51-9.24 \%$ of the total OTUs. ACE estimated by the abundance-based coverage was in the range of 4545-5455 and 4644-11,205 in urban and suburban rivers, respectively. The Chao 1 estimator of the species richness of community ranged from 4422 to 11,205 . However, there was no significant difference in Chao 1 estimator between urban and suburban rivers ( $t$-test, $p>0.05$ ) (Figure S3). Likewise, the Shannon index indicating overall diversity of community varied between 8.0 and 9.8, and S5 had the lowest Shannon index and U6 had the highest Shannon index (Table 2). Likewise, the Simpson index ranged from 0.95 to 1.00, and were generally higher in urban rivers than suburban rivers. The coverage varied between $98.5 \%$ and $98.8 \%$ in urban rivers, and between $97.4 \%$ and $98.7 \%$ in suburban rivers, indicating a good coverage estimated in this study. Generally, the OTUs, ACE and Chao 1 estimator of the bacterial richness indexes were slightly lower in urban rivers than in suburban rivers. However, Shannon and Simpson of bacterial diversity were higher in urban rivers than in suburban rivers (Figure S3). 
Table 1. Chemical properties of overlying water and sediments in the urban and suburban rivers.

\begin{tabular}{|c|c|c|c|c|c|c|c|c|c|c|c|c|c|}
\hline \multirow[b]{2}{*}{ Sites } & \multicolumn{6}{|c|}{ Overlying Water } & \multicolumn{7}{|c|}{ Sediment } \\
\hline & $\mathrm{pH}$ & $\begin{array}{c}\text { DO } \\
\left(\mathrm{mg} \mathrm{L}^{-1}\right)\end{array}$ & $\begin{array}{c}\text { DOC } \\
\left(\mathrm{mg} \mathrm{C} \mathrm{L}^{-1}\right)\end{array}$ & $\begin{array}{c}\mathrm{NO}_{3}^{-} \\
\left(\mathrm{mg} \mathrm{N} \mathrm{L}^{-1}\right) \\
\end{array}$ & $\begin{array}{c}\mathrm{NH}_{4}^{+} \\
\left(\mathrm{mg} \mathrm{N} \mathrm{L}^{-1}\right)\end{array}$ & $\begin{array}{c}\mathrm{NO}_{2}^{-} \\
\left(\mu \mathrm{N} \mathrm{L}^{-1}\right)\end{array}$ & $\begin{array}{c}\text { Sulfide } \\
\left(\mu \mathrm{g} \mathrm{S} \mathrm{g}^{-1}\right)\end{array}$ & $\begin{array}{c}\text { TOC } \\
\left(\mathrm{mg} \mathrm{C}^{-1}\right)\end{array}$ & $\begin{array}{c}\mathrm{TN} \\
\left(\mathrm{mg} \mathrm{N} \mathrm{g}^{-1}\right)\end{array}$ & $\mathrm{C} / \mathrm{N}$ & $\begin{array}{c}\mathrm{NO}_{3}^{-} \\
\left(\mu \mathrm{Ng}^{-1}\right) \\
\end{array}$ & $\begin{array}{c}\mathrm{NH}_{4}{ }^{+} \\
\left(\mu \mathrm{N} \mathrm{g}^{-1}\right)\end{array}$ & $\begin{array}{c}\mathrm{Fe}(\mathrm{II}) \\
\left(\mathrm{mg} \mathrm{Fe} \mathrm{g}^{-1}\right)\end{array}$ \\
\hline U1 & 6.9 & 2.89 & 21.8 & 3.81 & 15.4 & 8.03 & 158 & 10.8 & 1.51 & 7.17 & 2.25 & 188 & 9.87 \\
\hline U2 & 6.9 & 2.58 & 11.6 & 2.80 & 11.9 & 1.89 & 216 & 18.5 & 1.35 & 13.7 & 3.11 & 234 & 15.4 \\
\hline U3 & 7.0 & 2.68 & 14.4 & 3.39 & 13.7 & 89.5 & 152 & 33.2 & 3.15 & 10.5 & 2.93 & 147 & 7.89 \\
\hline $\mathrm{U} 4$ & 7.1 & 1.24 & 18.9 & 2.64 & 10.7 & 197 & 130 & 17.9 & 3.26 & 5.48 & 2.07 & 140 & 8.47 \\
\hline U5 & 6.8 & 2.01 & 13.6 & 9.06 & 6.43 & 12.1 & 4.15 & 22.1 & 2.43 & 9.12 & 3.25 & 240 & 9.83 \\
\hline U6 & 7.0 & 1.15 & 7.2 & 5.10 & 8.90 & 8.03 & 32.5 & 18.3 & 2.46 & 7.47 & 0.79 & 135 & 8.69 \\
\hline S1 & 7.3 & 2.65 & 19.6 & 3.29 & 0.24 & 5.47 & 515 & 15.3 & 1.06 & 14.4 & 0.32 & 38.8 & 9.01 \\
\hline S2 & 7.2 & 4.92 & 6.3 & 5.78 & 0.04 & 15.2 & 669 & 12.5 & 1.87 & 6.70 & 1.87 & 4.79 & 0.43 \\
\hline S3 & 7.3 & 1.31 & 5.8 & 2.77 & 0.02 & 12.1 & 274 & 22.8 & 3.11 & 7.34 & 1.35 & 52.5 & 9.68 \\
\hline S4 & 7.5 & 3.11 & 8.7 & 5.68 & 0.01 & 7.52 & 815 & 26.7 & 2.08 & 12.8 & 0.57 & 154 & 9.39 \\
\hline S5 & 7.2 & 2.01 & 7.7 & 4.15 & 0.02 & 17.3 & 172 & 26.4 & 2.03 & 13.0 & 0.38 & 115 & 8.66 \\
\hline S6 & 7.3 & 2.17 & 10.4 & 3.69 & 0.04 & 2.40 & 248 & 19.2 & 1.62 & 11.8 & 0.63 & 132 & 25.1 \\
\hline$p$ & $<0.001$ & 0.33 & 0.14 & 0.83 & $<0.001$ & 0.21 & 0.01 & 0.93 & 0.37 & 0.26 & 0.007 & 0.01 & 0.92 \\
\hline
\end{tabular}

The data was the mean value of triplicate samples measured. $p<0.05$ indicated that the properties differed significantly between grouped urban (U1-U6) and suburban (S1-S6) rivers.

Table 2. Bacterial richness and diversity characteristics of the bacterial sequences from pyrosequencing at each sample site.

\begin{tabular}{ccccccc}
\hline Sites & OTUs $^{\mathbf{a}}$ & ACE $^{\mathbf{b}}$ & Chao 1 $^{\mathbf{c}}$ & Shannon $^{\mathbf{d}}$ & Simpson $^{\mathbf{e}}$ & Coverage $^{\mathbf{f}}$ \\
\hline U1 & 3881 & 4799 & 4664 & 8.4 & 0.98 & 98.5 \\
U2 & 3883 & 4624 & 4515 & 8.7 & 0.99 & 98.7 \\
U3 & 4599 & 5423 & 5247 & 9.5 & 0.99 & 98.5 \\
U4 & 3870 & 4545 & 4422 & 8.9 & 0.99 & 98.8 \\
U5 & 4215 & 4987 & 4899 & 9.1 & 0.99 & 98.6 \\
U6 & 4762 & 5455 & 5308 & 9.8 & 1.00 & 98.6 \\
S1 & 4522 & 5288 & 5176 & 9.3 & 0.99 & 98.6 \\
S2 & 4756 & 7021 & 11,205 & 9.0 & 0.99 & 97.4 \\
S3 & 4468 & 5208 & 5121 & 9.2 & 0.99 & 98.6 \\
S4 & 4398 & 5270 & 5126 & 8.7 & 0.97 & 98.5 \\
S5 & 4137 & 4947 & 4787 & 8.0 & 0.95 & 98.5 \\
S6 & 4014 & 4741 & 4644 & 8.3 & 0.97 & 98.7
\end{tabular}

${ }^{a}$ Operation taxonomic units $\left(97 \%\right.$ similarity), ${ }^{\mathrm{b}}$ Abundance-based coverage estimators, ${ }^{\mathrm{c}}$ Richness estimate for an OTU definition, ${ }^{\mathrm{d}}$ Non-parametric Shannon diversity index. ${ }^{\mathrm{e}}$ The inverse Simpson index. ${ }^{\mathrm{f}}$ unit was $(\%)$. 


\subsection{Phylogenetic Affiliation of $16 S$ rRNA Gene Sequences}

Proteobacteria was the most abundant phylum of the bacterial communities, accounting for $48.85-76.74 \%$ of the total bacterial sequences. The Firmicutes, Bacteroidetes, Chloroflexi, Actinobacteria, and Acidobacteria were also the dominated bacterial communities, and their relative abundances accounted for $3.65-27.65 \%, 2.21-10.63 \%, 3.19-8.33 \%, 1.34-5.27 \%$, and $2.20-5.21 \%$ of total sequences, respectively. The relative abundances of Firmicutes and Nitrospirae were significantly higher in suburban rivers than in urban rivers ( $t$-test, $p<0.05$ ) (Table S1, Figure 2). Mean relative abundances indicated that Bacteroidetes, Verrucomicrobia, and Spirochaetes were more abundant in urban rivers than in suburban rivers. On the contrary, the relative abundances of Chloroflexi, Actinobacteria, Acidobacteria, and Gemmatimonadetes increased from $5.12 \%$ (urban rivers) to $5.38 \%$ (suburban rivers), $2.40 \%$ to $2.72 \%, 3.50 \%$ to $3.63 \%$, and $0.73 \%$ to $0.82 \%$, respectively. The abundant bacterial communities of Anaeromyxobacter, Burkholderia, Sulfurimonas, and Novosphingobium at the genus level were detected in urban rivers, while relatively high abundant Sphingopyxis, Polaromonas, Perlucidibaca, Flavobacterium, and Acinetobacter were observed in suburban rivers (Figure 3).

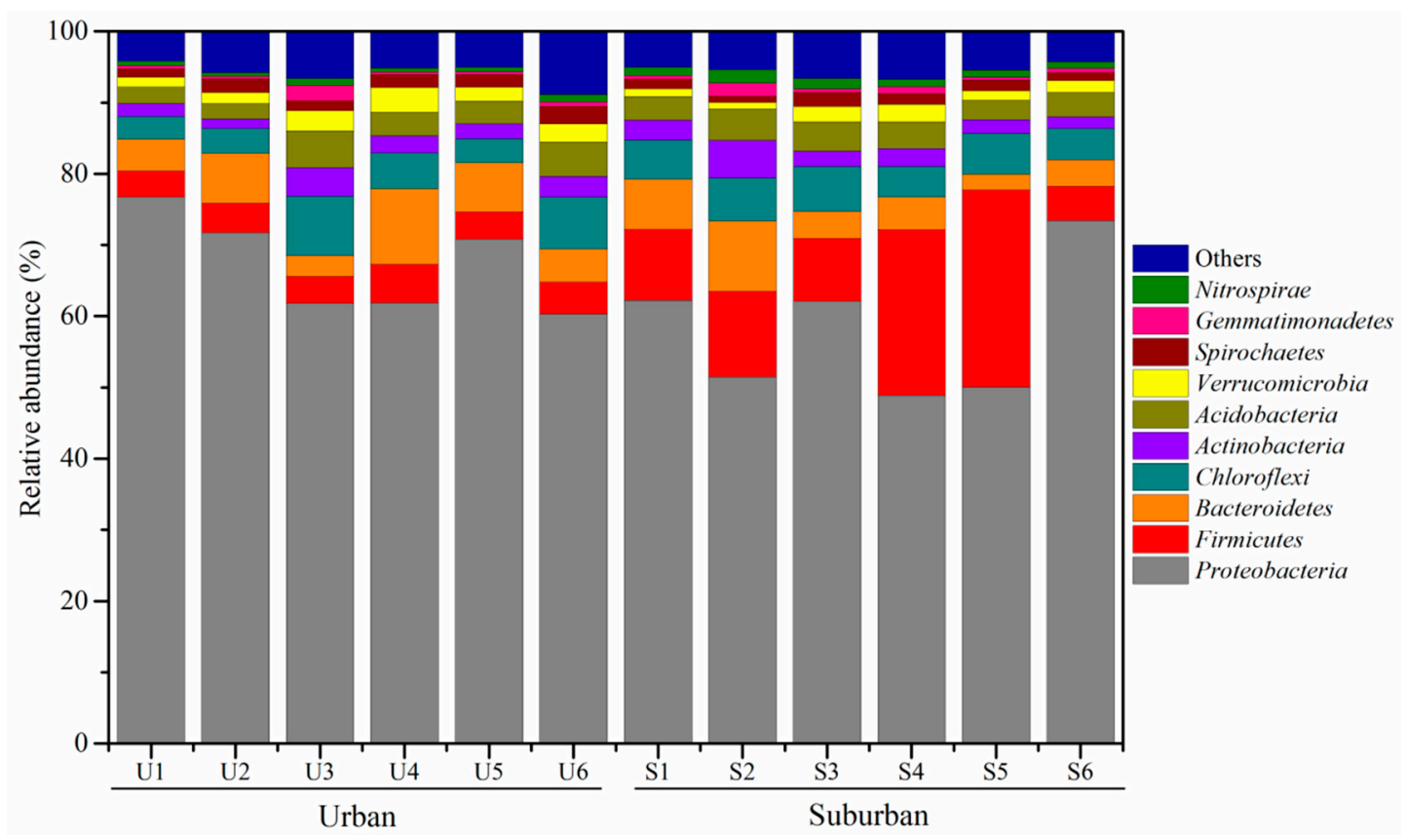

Figure 2. Relative abundance of sediment top 10 bacterial community compositions at phylum level. The relative abundance is expressed as the percentage of the targeted sequences to the total high-quality bacterial sequences of samples. "Others" refers to the taxa with a maximum abundance of $<1 \%$ in any sample.

At the family level, bacterial sequences were assigned to 392 families. The top 36 abundant families accounted for $50.7-66.8 \%$ of total bacterial sequences. 25 families assigned to phylum Proteobacteria accounted for $69.4 \%$ of the top families (Table S1). Rhodocyclaceae (6.26-12.96\%), Comamonadaceae (2.60-6.08\%), Gallionellaceae (2.11-4.74\%), Geobacteraceae (2.07-3.96\%) and Hydrogenophilaceae (1.68-3.73\%) were also the most abundant communities in urban rivers, while Rhodocyclaceae $(4.17-6.97 \%)$, Comamonadaceae (2.33-5.43\%), Anaerolineaceae (2.34-4.38\%), Gallionellaceae (2.11-4.74\%), Planococcaceae (2.11-8.85\%), and Xanthomonadaceae (1.60-3.30\%) contributed substantially to the bacterial communities in suburban rivers. 


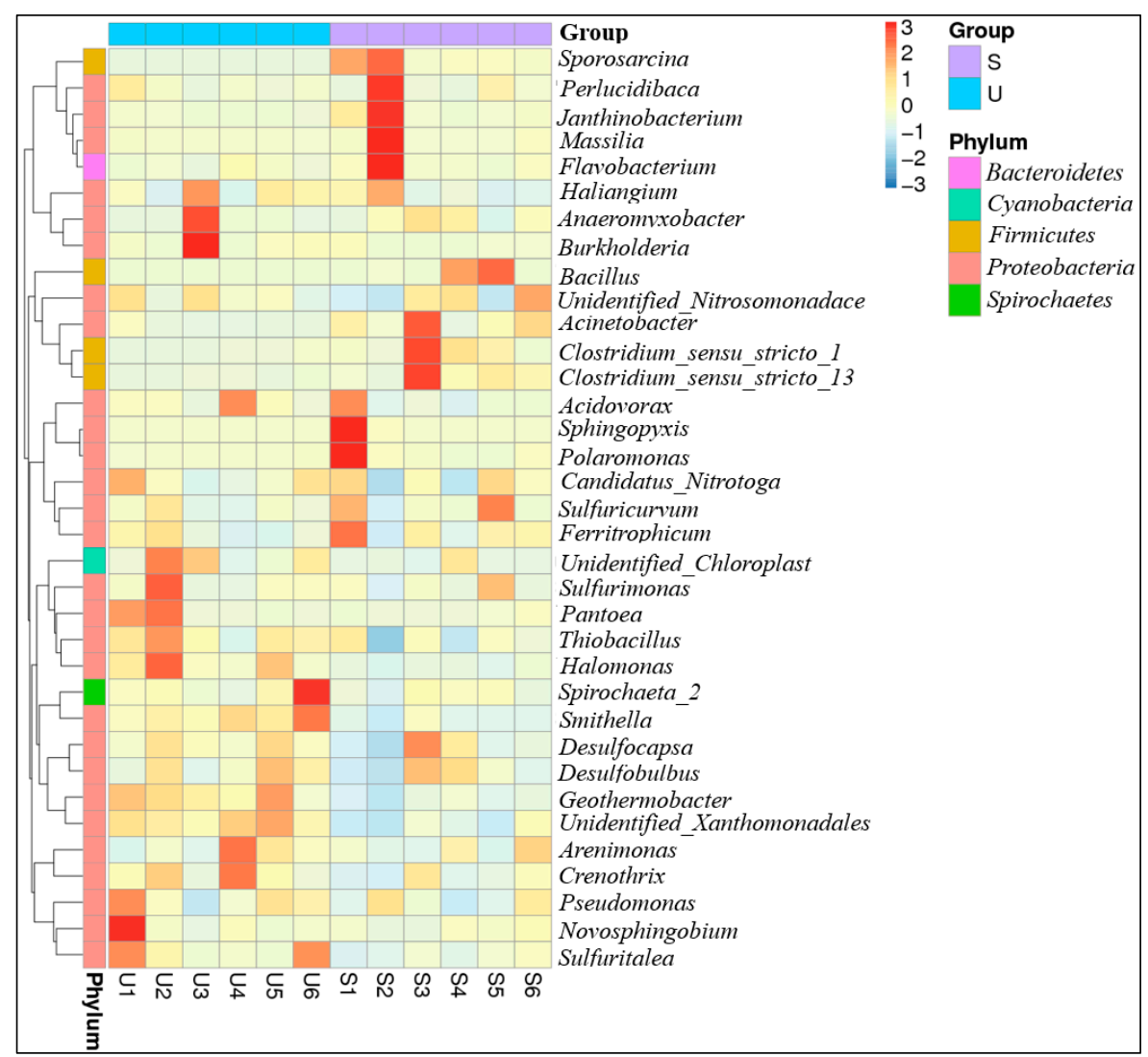

Figure 3. Heat map of top abundant genus level in each sample. The color intensity in each cell indicates the transformed relative abundance $\left[\log _{2}(x+0.01)\right]$ of a family in a sample, referring to color key at the right top of the figure. The families in blue or red showed lower or higher relative abundances among samples.

However, the bacterial community was dominated by the family Bacillaceae at sites S4 and S5, accounting for $16.63 \%$ and $21.33 \%$, respectively. WCHB1-69, Syntrophaceae, Rhodocyclaceae, Geobacteraceae, unidentified_Xanthomonadales, and Spongiibacteraceae were significantly higher in urban rivers than in suburban rivers ( $t$-test, $p<0.05$ ), while only relative abundance of Planococcaceae (affiliated to phylum Firmicutes) was significantly lower in urban rivers than in suburban rivers ( $t$-test, $p<0.05)$.

\subsection{Factors Shaping Bacterial Community Structure and Diversity}

The result of nonmetric multidimensional scaling ordination analysis indicated a differentiation in the bacterial communities between urban and suburban rivers (stress $=0.073$, Figure 4). Bacterial community structure was further evidenced by an analysis of similarity (ANOSIM), which revealed that the site condition may be the important determinants of bacterial community composition (Figure S4). The Pearson's correlation analysis indicated that ACE and Chao 1 estimator were significantly and positively related with DO, while negatively with Fe(II) ( $t$-test, $p<0.05$; Table 3 ). In addition, significantly negative relationships were observed between sediment $\mathrm{NH}_{4}{ }^{+}$and OTUs, ACE and Chao 1 estimator $(p<0.05)$. The Pearson' analysis revealed that $\mathrm{NH}_{4}{ }^{+}$and $\mathrm{NO}_{3}{ }^{-}$were the main properties that significantly affected the abundance of phylum Firmicutes, Nitrospirae, Verrucomicrobia $(p<0.05 ;$ Table S2). In addition, the scatter plot of NMDS indicated strong differences in the bacterial communities between urban and suburban rives, with most urban rivers clustering on the left side of the $y$-axis and suburban rivers clustering on the right side of the y-axis (Figure 4). 


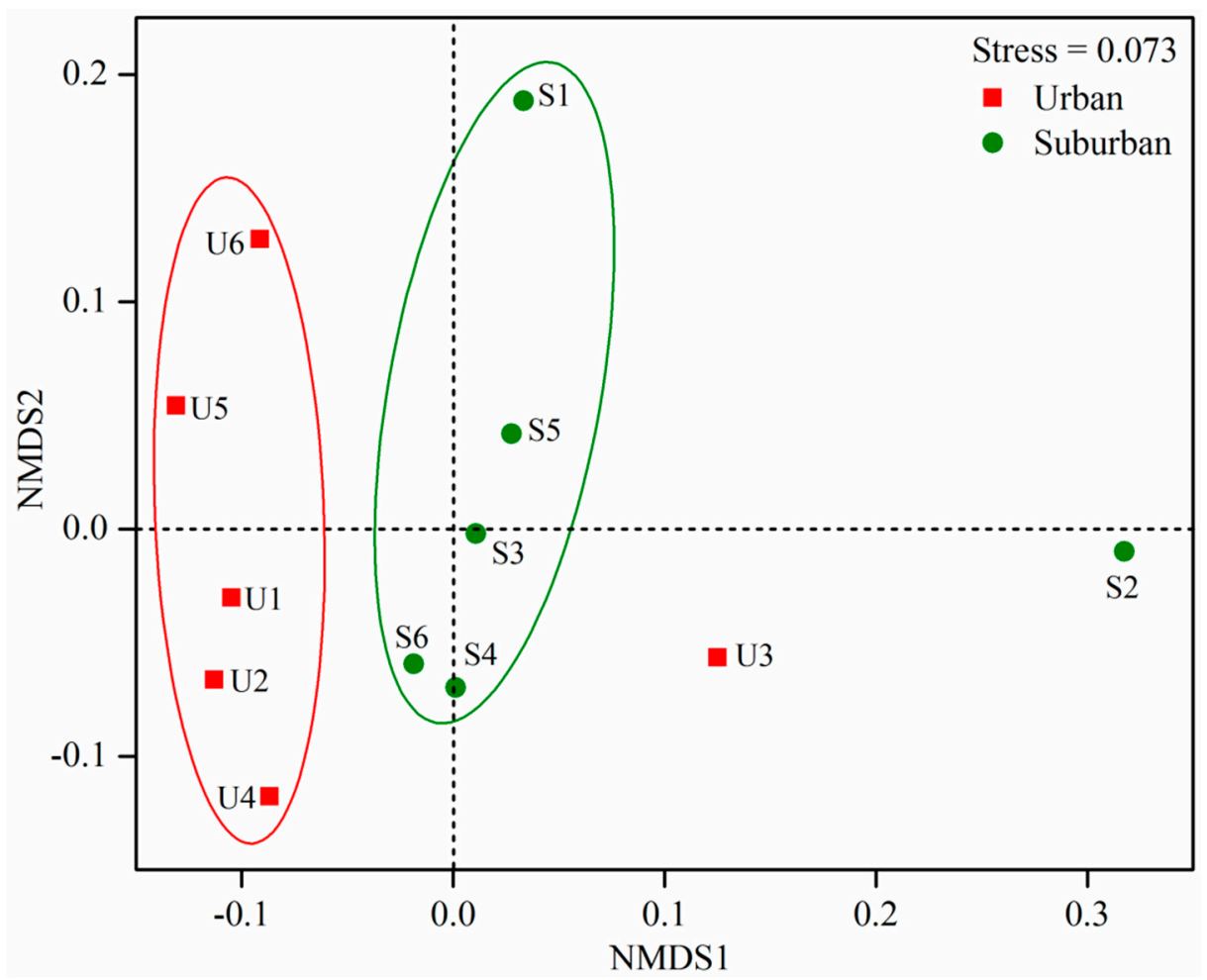

Figure 4. Nonmetric multidimensional scaling (NMDS) ordination of the dissimilarity (Bray-Curtis distance) in bacterial community composition.

Table 3. Summary of Pearson's correlation analysis between chemical properties and bacterial richness and diversity indexes.

\begin{tabular}{cccccc}
\hline Environmental Parameters & OTUs & ACE & Chao & Shannon & Simpson \\
\hline $\mathrm{pH}$ & 0.33 & 0.29 & 0.21 & -0.17 & -0.43 \\
$\mathrm{DO}$ & 0.26 & $0.69^{*}$ & $0.76^{*}$ & -0.16 & -0.08 \\
$\mathrm{NO}_{3}^{-\mathrm{a}}$ & 0.26 & 0.31 & 0.28 & 0.11 & -0.02 \\
$\mathrm{NH}_{4}^{+\mathrm{a}}$ & -0.34 & -0.35 & -0.32 & 0.20 & 0.46 \\
$\mathrm{NO}_{2}^{-}$ & -0.23 & -0.21 & -0.14 & 0.14 & 0.25 \\
$\mathrm{Fe}(\mathrm{II})$ & -0.55 & $-0.66^{*}$ & $-0.59 *$ & -0.39 & -0.34 \\
$\mathrm{Sulfide}$ & 0.34 & 0.53 & 0.51 & -0.10 & -0.20 \\
$\mathrm{TOC}$ & 0.18 & -0.15 & -0.32 & 0.09 & -0.25 \\
$\mathrm{TN}$ & 0.18 & -0.02 & -0.09 & 0.40 & 0.28 \\
$\mathrm{C} / \mathrm{N}$ & -0.10 & -0.24 & -0.31 & -0.29 & -0.46 \\
$\mathrm{NO}_{3}^{-\mathrm{b}}$ & -0.26 & -0.08 & 0.02 & 0.17 & 0.49 \\
$\mathrm{NH}_{4}^{+\mathrm{b}}$ & $-0.60 *$ & $-0.65 *$ & $-0.60 *$ & -0.19 & -0.03 \\
\hline
\end{tabular}

a indicates properties of overlying water, ${ }^{\mathrm{b}}$ indicates properties of sediment. ${ }^{*} p<0.05$ and ${ }^{* *} p<0.01$ indicate a significant correlation.

\subsection{Redundancy Analysis}

Redundancy analysis (RDA) was performed to reveal the relationships between bacterial richness and diversity and environmental variables. Ordination triplets of first two axes (RDA1 and RDA2) explained $73.2 \%$ of the total variance (Figure 5). Results of RDA indicated that bacterial richness and diversity were significantly correlated with overlying water and sediment parameters. The first axis of RDA1 was positively correlated with overlying water $\mathrm{DO}, \mathrm{pH}$ and $\mathrm{NO}_{3}{ }^{-}$, sediment sulfide, but negatively correlated with sediment $\mathrm{NH}_{4}{ }^{+}$, water $\mathrm{NH}_{4}{ }^{+}$and $\mathrm{C} / \mathrm{N}$, which explained $48.7 \%$ of the total variance ( $p<0.05$, Monte Carlo based on 999 permutations). The second axis of RDA2 was positively correlated with TOC and TN, negatively related to water $\mathrm{NO}_{2}{ }^{-}$and sediment $\mathrm{NO}_{3}{ }^{-}$, explaining $24.5 \%$ of the total variance ( $p<0.05$, Monte Carlo based on 999 permutations). DO had a significantly 
positive effect on Chao 1 estimator and ACE ( $p<0.05$, based on 999 permutations). Sediment $\mathrm{NH}_{4}{ }^{+}$ showed a significantly negative influence on OTUs, ACE and Chao 1 estimator $(p<0.05$, based on 999 permutations).

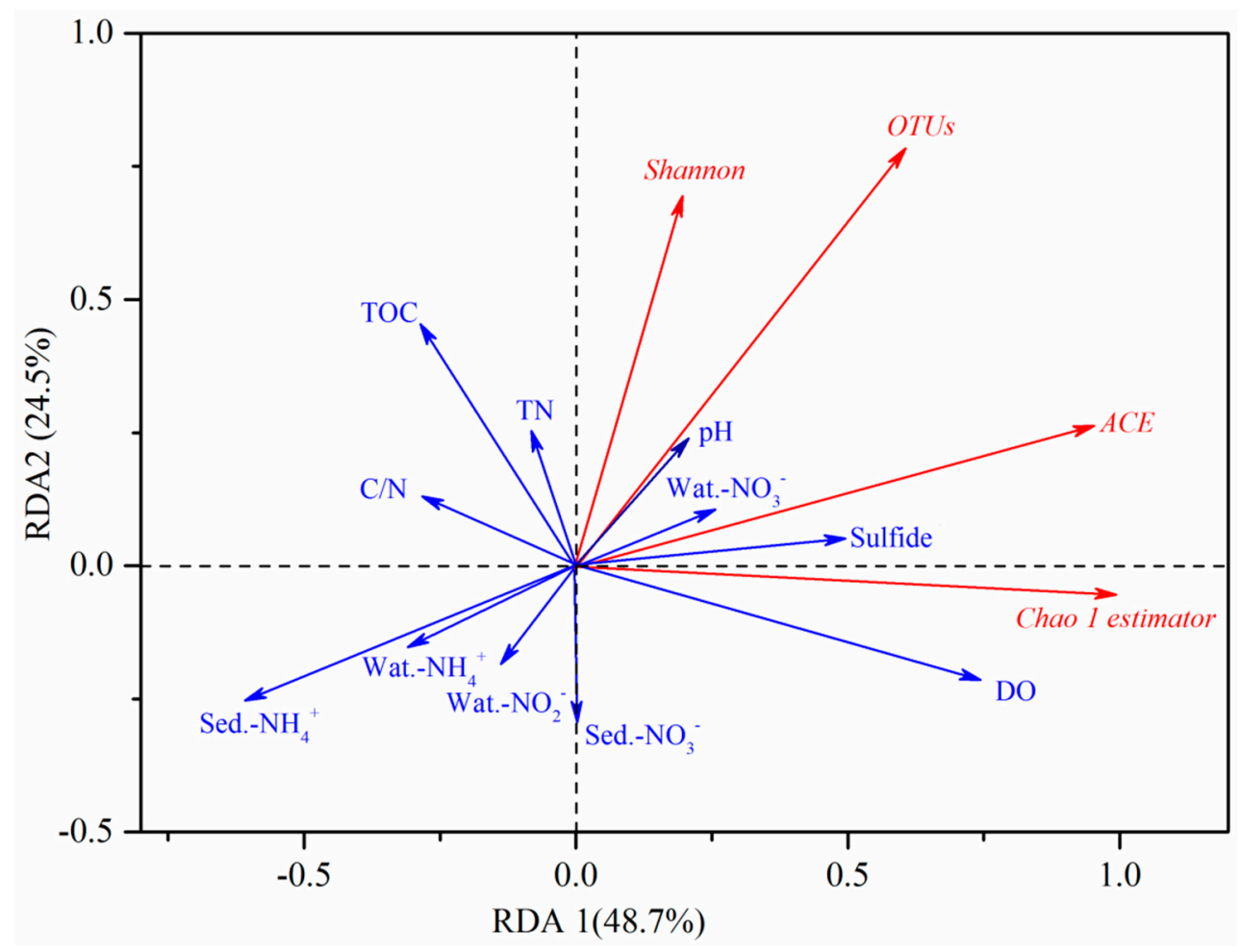

Figure 5. Redundancy analysis (RDA) compared to bacterial community richness and diversity and environmental properties. The percentages of total variation were explained by the first two axes are shown in parentheses.

\section{Discussion}

Urban rivers in rapid urbanization areas are easily affected by the land use and human activities $[6,26]$. Subsequently, the chemical properties and ecological function of overlying water and sediment in urban rivers are susceptible to anthropogenic pollutant inputs $[6,10]$. The main source of nitrogen pollution in urban rivers is household and industrial sewage discharge [17]. In addition, the content of reactive nitrogen in urban rivers increases intensively at a rapid rate under urbanization [11]. Therefore, shifts in the bacterial community composition and diversity are likely to occur in response to the increasing nitrogen pollution in urban rivers $[27,28]$. In this study, the nitrogen enrichment in the urban rivers could contribute to bacterial community shifts in sediments. Also, particular bacterial communities are potentially resilient to nitrogen pollution.

Previous studies reported that the dominant bacterial phyla communities in urban rivers were Proteobacteria, Firmicutes, Actinobacteria, Bacteroidetes, and Spirochaetes, and their relative abundances were related to fecal pollution $[8,28]$. In addition, it has been reported that the bacterial phyla in the urban rivers of Nanjing city were dominated by Proteobacteria, Actinobacteria, Bacteroidetes, following by Verrucomicrobia, Chlorobi, Firmicutes, Planctomycetes, Cyanobacteria and Chloroflexi [28]. However, the bacterial community differed with a season variation and by sample site, indicating that the environmental properties strongly regulate the dynamics of bacterial communities in urban rivers [28]. A recent study has documented that nitrogen addition can increase the relative abundances of Proteobacteria and Actinobacteria, but decrease the relative abundances of Acidobacteria, Verrucomicrobia, Planctomycetes, and WD272 [29]. Importantly, the relative abundances of Burkholderia and Rhizomicrobium for nitrogen cycling bacterial communities increased with the nitrogen addition [29]. Likewise, our study also indicated that a high abundance of Actinobacteria was observed in the high $\mathrm{NH}_{4}{ }^{+}$content 
sites of the urban rivers (Figure 2). The bacterial communities in sediments of the Upper Mississippi River were dominated by Proteobacteria, Bacteroidetes, Acidobacteria, and Actinobacteria, and these bacterial communities varied temporally and spatially [30]. In our study, Firmicutes, Bacteroidetes, Chloroflexi, Actinobacteria, and Acidobacteria were dominant in the river sediments. However, the relative abundances of Bacteroidetes, Verrucomicrobia, and Spirochaetes were higher in urban rivers than in suburban rivers, while the relative abundances of Chloroflexi, Actinobacteria, Acidobacteria, and Gemmatimonadetes were higher in suburban rivers than in urban rivers [8]. In an eutrophic lake, $\mathrm{NO}_{3}{ }^{-}$ content level dominated the bacterial community composition [31]. However, the bacterial community was dominated by Actinobacteria, Beta- and Alphaproteobacteria in the sediments of the nitrogen-enriched lake [31]. The difference in the bacterial community composition between urban and suburban rives could be partly attributed to the important effects of sediment $\mathrm{NH}_{4}{ }^{+}$on the bacterial communities.

The significant difference in chemical properties between urban and suburban rivers was the inorganic nitrogen content, which may play a crucial role in the special bacterial variations. $\mathrm{NH}_{4}{ }^{+}$ in overlying water and $\mathrm{NH}_{4}{ }^{+} / \mathrm{NO}_{3}{ }^{-}$in sediments were significantly higher in urban rivers than in suburban rivers (Table 1). Domestic wastewaters and human excreta contribute the most to $\mathrm{NH}_{4}{ }^{+}$in urban rivers $[9,11,32,33]$. Therefore, the $\mathrm{NH}_{4}{ }^{+}$content likely contributes to the abundance of bacterial communities and variations of special communities. The OTUs, ACE, Chao 1 estimator in this study were negatively related to sediment $\mathrm{NH}_{4}{ }^{+}$content (Table 3), indicating that the heavy $\mathrm{NH}_{4}{ }^{+}$pollution reduces the bacterial richness in urban rivers. Drury et al. reported that $\mathrm{NH}_{4}{ }^{+}$enrichment in urban sediment supply the substrate for nitrification process [6]. The abundance of Nitrospirae was higher in urban river sediment than in suburban river sediment because Nitrospira species are nitrifying Gram-negative chemoautotrophic bacteria [12]. The relative abundances of Firmicutes and Nitrospirae were lower in suburban rivers with $\mathrm{NH}_{4}{ }^{+}$enrichment, suggesting that excessive $\mathrm{NH}_{4}{ }^{+}$can inhibit these two bacterial communities although they are involved in the fecal pollution and nitrogen cycling. The relative abundance of Nitrospirae in this study was significantly higher in suburban rivers than in urban rivers $(t$-test, $p<0.05)$, which suggested that the serious $\mathrm{NH}_{4}{ }^{+}$pollution had a negative influence on this bacterial community. Although the $\mathrm{NH}_{4}{ }^{+}$contents $\left(6.4-15.4 \mathrm{mg} \mathrm{N} \mathrm{L}^{-1}\right)$ are extremely high in the urban rivers, nitrifying bacteria cannot be directly inhibited by the toxicity of the $\mathrm{NH}_{4}{ }^{+}$in this study due to that nitrifying bacteria can work with high $\mathrm{NH}_{4}{ }^{+}$amount (up to $196 \mathrm{mg} \mathrm{N} \mathrm{L}^{-1}$ ) [34]. Thus, the attribute in this result may be that the nitrifiers were inhibited by low $\mathrm{DO}$ concentration in the urban rivers, which was induced by excessive $\mathrm{NH}_{4}{ }^{+}$. Meanwhile, this result may be also attributed to other pollutants, such as heavy metals and permanent organic pollutants, as reported in previous studies in urban river ecosystems [35-38]. In addition, Firmicutes is the Gram-positive heterotrophic bacteria for nutrient cycling, the richness of Firmicutes was thus affected by the fecal pollution [8], and the Firmicutes community was the indicator of $\mathrm{NH}_{4}{ }^{+}$and $\mathrm{NO}_{3}{ }^{-}$derived from anthropogenic activities [38]. On the contrary, our results showed that more abundant Firmicutes was observed in suburban rivers compared to urban rivers, because excess amount of $\mathrm{NH}_{4}{ }^{+}$pose a noxious action to Firmicutes in the high content of $\mathrm{NH}_{4}{ }^{+}$in the urban rivers [39]. Therefore, $\mathrm{NH}_{4}{ }^{+}$from anthropogenic activities in the urban rivers may contribute to the lower abundance of Nitrospirae and Firmicutes bacteria [6].

Due to the increasing nitrogen load in rivers, nitrogen makes a stronger contribution to microbial community dissimilarities than other variables in urban rivers [28]. It has been suggested that $\mathrm{NH}_{4}{ }^{+}$was a critical environmental parameter determining the composition of the soil bacterial community [29]. In this study, the OTUs, ACE and Chao 1 estimator decreased with the increasing $\mathrm{NH}_{4}{ }^{+}$content, suggesting that $\mathrm{NH}_{4}{ }^{+}$pollution likely contributes to decrease in bacterial diversity. However, in the present study, sediment $\mathrm{NH}_{4}{ }^{+}$had a negative influence on the bacterial diversity, suggesting the decrease in bacterial richness in response to the serious nitrogen pollution because only a few bacterial communities may survive in the environments impacted by the excessive nitrogen. The negative effect of $\mathrm{NH}_{4}{ }^{+}$on bacterial richness was also evidenced in soil environments [40]. In addition, the occurrence of Microcystis can decrease the bacterial diversity since the eutrophication driven by the nitrogen [31]. In addition, sediment $\mathrm{NH}_{4}{ }^{+}$was identified as the key driving factors of changes in the bacterial 
composition [17]. Therefore, the nitrogen pollution in rivers had both direct and indirect influences on the bacterial diversity. In addition, the positive correlation between DO and bacterial indices suggested that the high DO content was favorable for aerobic bacterial communities in the rivers.

In addition to the nitrogen, $\mathrm{DO}, \mathrm{pH}$ and sulfide are also the important factors shaping the bacterial structure and composition in wide land and aquatic ecosystems [28,41]. The decrease in DO content may be attributed to the serious nitrogen pollution, resulting in the degradation of water quality in the rivers. It has been reported that DO has a considerable influence on the bacterial composition because the DO content level directly affects the organism metabolism [42]. In this study, the positive correlation between DO and both ACE and Chao 1 estimator further suggested the importance of DO on the regulation of the bacterial richness in the urban rivers. It has been reported that sulfide has a negative influence on microbial metabolism [43]. In this study, a negative correlation between ACE and sulfide further was also observed. In addition, temperature can contribute to the differences in bacterial phyla abundances, because relatively high temperature can promote the bacterial activity $[30,44]$. The chemical properties in overlying water were significantly correlated with those in the sediments (Table S3), further indicating that properties of overlying water have considerable influences on the bacterial community structure and diversity (Table 1). Perryman et al. reported that the denitrifying community differs significantly between urban sediments and non-urban sediments because the nitrate is seriously polluted in urban sediment [27]. Local environmental conditions play a key role in shaping bacterial communities and the dynamics of environmental factors could be important in revealing bacterial distribution in the study area [45]. In this study, the local sites conditions and chemical properties varied between urban and suburban rivers, which likely resulted in the variations of the bacterial communities [38].

\section{Conclusions}

Our results indicate shifts in bacterial richness and diversity in response to the nitrogen pollution in highly urbanized river sediments. The overlying water $\mathrm{NH}_{4}{ }^{+}$and sediment $\mathrm{NH}_{4}{ }^{+}$and $\mathrm{NO}_{3}{ }^{-}$was significantly higher in urban rivers than in suburban rivers, indicating that heavy human activities contribute to the $\mathrm{NH}_{4}{ }^{+}$pollution in urban rivers. The significant decrease in the abundances of phyla Firmicutes and Nitrospirae, and the increase in phyla Bacteroidetes, Verrucomicrobia, Spirochaetes dominated the dynamics of bacterial community structure in response to the nitrogen pollution. The bacterial community shifts at the family level showed that relative abundances of Syntrophaceae, Rhodocyclaceae, Geobacteraceae, unidentified_Xanthomonadales and Spongiibacteraceae were higher in urban rivers in suburban rivers, which could be potentially beneficial to high nitrogen stress. $\mathrm{NO}_{3}{ }^{-}$and $\mathrm{NH}_{4}{ }^{+}$were significantly correlated with the abundances of Firmicutes, Nitrospirae, Actinobacteria. In addition, $\mathrm{NO}_{3}{ }^{-}$and $\mathrm{NH}_{4}{ }^{+}$had direct and indirect influences on the bacterial richness and diversity, suggesting the negative effects of nitrogen load on bacterial communities. Overall, the changes in bacterial structure and declining in bacterial richness and diversity were greatly affected by the nitrogen pollution. Furthermore, increasing nitrogen input to urban rivers caused by the rapid urbanization can affect not only the chemical properties, but also the bacterial community compositions, and may further alter the ecological importance of specific communities in the river environments.

Supplementary Materials: The following are available online at http://www.mdpi.com/1660-4601/16/20/3794/s1, Figure S1: The landscape of a river heavily polluted by anthropogenic wastewater discharge in the study area, Figure S2: Concentrations of inorganic nitrogen forms in urban and suburban rivers, Figure S3: Diversity indices of bacterial community in urban and suburban rivers, Figure S4: Analysis of similarity about the bacterial community, Table S1: Relative abundance (\%) of top 36 abundant families in the samples. $P$ _value of ANOVA analysis indicated significant difference of bacterial abundance between grouped urban and suburban rivers, Table S2: Relationship between properties and relative abundances of phylum bacterial communities, Table S3: Correlations among geochemical properties in overlying water and sediment.

Author Contributions: Methodology, X.L. and X.L.; software, X.L. and K.L.; formal analysis, X.L., D.G., and K.L.; investigation, X.L. and X.L.; data curation, X.L. and X.L.; writing-original draft preparation, X.L. and X.L.; writing-review and editing, X.L., K.L., D.G., and X.L.; visualization, X.L. and D.G.; funding acquisition, X.L. and X.L. 
Funding: This research was funded by Key Laboratory of Yangtze River Water Environment, Ministry of Education (Tongji University), China, grant number YRWEF201804". It was also funded by the National Natural Science Foundation of China (grant number 41701548), and China Postdoctoral Science Foundation (grant number 2019M653151).

Conflicts of Interest: The authors declare no conflict of interest.

\section{References}

1. Galloway, J.N.; Townsend, A.R.; Erisman, J.W.; Bekunda, M.; Cai, Z.; Freney, J.R.; Martinelli, L.A.; Seitzinger, S.P.; Sutton, M.A. Transformation of the nitrogen cycle: Recent trends, questions, and potential solutions. Science 2008, 320, 889-892. [CrossRef]

2. Schlesinger, W.H. On the fate of anthropogenic nitrogen. Proc. Natl. Acad. Sci. USA 2009, 106, $203-208$. [CrossRef] [PubMed]

3. Sinha, E.; Michalak, A.; Balaji, V. Eutrophication will increase during the 21st century as a result of precipitation changes. Science 2017, 357, 405-408. [CrossRef] [PubMed]

4. Grimm, N.B.; Foster, D.; Groffman, P.; Grove, J.M.; Hopkinson, C.S.; Nadelhoffer, K.J.; Pataki, D.E.; Peters, D.P. The changing landscape: Ecosystem responses to urbanization and pollution across climatic and societal gradients. Front. Ecol. Environ. 2008, 6, 264-272. [CrossRef]

5. Yu, Z.J.; Deng, H.G.; Wang, D.Q.; Ye, M.W.; Tan, Y.J.; Li, Y.J.; Chen, Z.L.; Xu, S.Y. Nitrous oxide emissions in the Shanghai river network: Implications for the effects of urban sewage and IPCC methodology. Glob. Change Biol. 2013, 19, 2999-3010. [CrossRef] [PubMed]

6. Drury, B.; Rosi-Marshall, E.; Kelly, J.J. Wastewater treatment effluent reduces the abundance and diversity of benthic bacterial communities in urban and suburban rivers. Appl. Environ. Microb. 2013, 79, 1897-1905. [CrossRef]

7. Zhao, J.; Lin, L.Q.; Yang, K.; Liu, Q.X.; Qian, G.R. Influences of land use on water quality in a reticular river network area: A case study in Shanghai, China. Landsc. Urban Plan. 2015, 137, 20-29. [CrossRef]

8. Ibekwe, A.M.; Ma, J.; Murinda, S.E. Bacterial community composition and structure in an urban river impacted by different pollutant sources. Sci. Total Environ. 2016, 566, 1176-1185. [CrossRef]

9. Zhang, X.H.; Wu, Y.Y.; Gu, B.J. Urban rivers as hotspots of regional nitrogen pollution. Environ. Pollut. 2015, 205, 139-144. [CrossRef]

10. Suriya, J.; Shekar, M.C.; Nathani, N.M.; Suganya, T.; Bharathiraja, S.; Krishnan, M. Assessment of bacterial community composition in response to uranium levels in sediment samples of sacred Cauvery River. Appl. Microbiol. Biot. 2017, 101, 1-11. [CrossRef]

11. Gu, B.J.; Dong, X.L.; Peng, C.H.; Luo, W.D.; Chang, J.; Ge, Y. The long-term impact of urbanization on nitrogen patterns and dynamics in Shanghai, China. Environ. Pollut. 2012, 171, 30-37. [CrossRef] [PubMed]

12. Altmann, D.; Stief, P.; Amann, R.; De Beer, D.; Schramm, A. In situ distribution and activity of nitrifying bacteria in freshwater sediment. Environ. Microbiol. 2003, 5, 798-803. [CrossRef] [PubMed]

13. Zhang, H.H.; Zhao, Z.F.; Chen, S.N.; Kang, P.L.; Wang, Y.; Feng, J.; Jia, J.Y.; Yan, M.M.; Wang, Y.; Xu, L. Paracoccus versutus KS293 adaptation to aerobic and anaerobic denitrification: Insights from nitrogen removal, functional gene abundance, and proteomic profiling analysis. Bioresour. Technol. 2018, 260, 321-328. [CrossRef] [PubMed]

14. Zhang, H.H.; Wang, Y.; Chen, S.N.; Zhao, Z.F.; Feng, J.; Zhang, Z.H.; Lu, K.Y.; Jia, J.Y. Water bacterial and fungal community compositions associated with urban lakes, Xi'an, China. Int. J. Environ. Res. Public Health 2018, 15, 469. [CrossRef]

15. Fortunato, C.S.; Eiler, A.; Herfort, L.; Needoba, J.A.; Peterson, T.D.; Crump, B.C. Determining indicator taxa across spatial and seasonal gradients in the Columbia River coastal margin. ISME J. 2013, 7, 1899. [CrossRef] [PubMed]

16. Niu, L.H.; Li, Y.; Xu, L.L.; Wang, P.F.; Zhang, W.L.; Wang, C.; Cai, W.; Wang, L.Q. Ignored fungal community in activated sludge wastewater treatment plants: Diversity and altitudinal characteristics. Environ. Sci. Pollut. Res. 2017, 24, 4185-4193. [CrossRef]

17. Cheng, L.; Li, X.F.; Lin, X.B.; Hou, L.J.; Liu, M.; Li, Y.; Liu, S.; Hu, X.T. Dissimilatory nitrate reduction processes in sediments of urban river networks: Spatiotemporal variations and environmental implications. Environ. Pollut. 2016, 219, 545-554. [CrossRef] 
18. Lin, X.B.; Li, X.F.; Gao, D.Z.; Liu, M.; Cheng, L. Ammonium production and removal in the sediments of Shanghai River networks: Spatiotemporal variations, controlling factors, and environmental implications. J. Geophys. Res. Biogeosci. 2017, 122, 2461-2478. [CrossRef]

19. Wakelin, S.A.; Colloff, M.J.; Kookana, R.S. Effect of wastewater treatment plant effluent on microbial function and community structure in the sediment of a freshwater stream with variable seasonal flow. Appl. Environ. Microbiol. 2008, 74, 2659-2668. [CrossRef]

20. Pan, H.Y.; Zhuang, M.F.; Geng, Y.; Wu, F.; Dong, H.J. Emergy-based ecological footprint analysis for a mega-city: The dynamic changes of Shanghai. J. Clean Prod. 2019, 210, 552-562. [CrossRef]

21. Hou, L.J.; Zheng, Y.L.; Liu, M.; Gong, J.; Zhang, X.L.; Yin, G.Y.; You, L. Anaerobic ammonium oxidation (anammox) bacterial diversity, abundance, and activity in marsh sediments of the Yangtze Estuary. J. Geophys. Res. Biogeosci. 2013, 118, 1237-1246. [CrossRef]

22. Lovley, D.R.; Phillips, E.J. Rapid assay for microbially reducible ferric iron in aquatic sediments. Appl. Environ. Microb. 1987, 53, 1536-1540.

23. Magoč, T.; Salzberg, S.L. FLASH: Fast length adjustment of short reads to improve genome assemblies. Bioinformatics 2011, 27, 2957-2963. [CrossRef] [PubMed]

24. Shannon, C.E. A mathematical theory of communication, ACMSIG Mobile: Mobile Computing and Communications Review. Sci. Res. 2001, 5, 3-55.

25. Chao, A. Nonparametric estimation of the number of classes in a population. Scand. J. Stat. 1984, 11, 265-270.

26. Palmer, M.A.; Covich, A.P.; Lake, S.; Biro, P.; Brooks, J.J.; Cole, J.; Dahm, C.; Gibert, J.; Goedkoop, W.; Martens, K. Linkages between aquatic sediment biota and life above sediments as potential drivers of biodiversity and ecological processes: A disruption or intensification of the direct and indirect chemical, physical, or biological interactions between aquatic sediment biota and biota living above the sediments may accelerate biodiversity loss and contribute to the degradation of aquatic and riparian habitats. BioScience 2000, 50, 1062-1075.

27. Perryman, S.E.; Rees, G.N.; Walsh, C.J. Analysis of denitrifying communities in streams from an urban and non-urban catchment. Aquat. Ecol. 2008, 42, 95-101. [CrossRef]

28. Gao, Y.; Wang, C.C.; Zhang, W.G.; Di, P.P.; Yi, N.; Chen, C.R. Vertical and horizontal assemblage patterns of bacterial communities in a eutrophic river receiving domestic wastewater in southeast China. Environ. Pollut. 2017, 230, 469-478. [CrossRef]

29. Nie, Y.X.; Wang, M.C.; Zhang, W.; Ni, Z.; Hashidoko, Y.; Shen, W.J. Ammonium nitrogen content is a dominant predictor of bacterial community composition in an acidic forest soil with exogenous nitrogen enrichment. Sci. Total Environ. 2018, 624, 407-415. [CrossRef]

30. Staley, C.; Gould, T.J.; Wang, P.; Phillips, J.; Cotner, J.B.; Sadowsky, M.J. Species sorting and seasonal dynamics primarily shape bacterial communities in the Upper Mississippi River. Sci. Total Environ. 2015, 505, 435-445. [CrossRef]

31. Su, X.M.; Steinman, A.D.; Tang, X.M.; Xue, Q.J.; Zhao, Y.Y.; Xie, L.Q. Response of bacterial communities to cyanobacterial harmful algal blooms in Lake Taihu, China. Harmful Algae 2017, 68, 168-177. [CrossRef] [PubMed]

32. Grimm, N.B.; Faeth, S.H.; Golubiewski, N.E.; Redman, C.L.; Wu, J.G.; Bai, X.M.; Briggs, J.M. Global change and the ecology of cities. Science 2008, 319, 756-760. [CrossRef] [PubMed]

33. Ma, L.; Wang, F.H.; Zhang, W.F.; Ma, W.Q.; Velthof, G.; Qin, W.; Oenema, O.; Zhang, F.S. Environmental assessment of management options for nutrient flows in the food chain in China. Environ. Sci. Technol. 2013, 47, 7260-7268. [CrossRef] [PubMed]

34. Schramm, A.; Larsen, L.H.; Revsbech, N.P.; Amann, R. Structure and function of a nitrifying biofilm as determined by microelectrodes and fluorescent oligonucleotede probes. Water Sci. Technol. 1997, 36, $263-270$. [CrossRef]

35. Zhang, X.; Gu, Q.; Long, X.E.; Li, Z.L.; Liu, D.X.; Ye, D.H.; He, C.Q.; Liu, X.Y.; Kristiina, V.; Chen, X.P. Anthropogenic activities drive the microbial community and its function in urban river sediment. J. Soil Sediments 2016, 16, 716-725. [CrossRef]

36. Yang, X.; Huang, S.; Wu, Q.; Zhang, R.; Liu, G. Diversity and vertical distributions of sediment bacteria in an urban river contaminated by nutrients and heavy metals. Front. Env. Sci. Eng. 2013, 7, 851-859. [CrossRef]

37. Margot, J.; Rossi, L.; Barry, D.A.; Holliger, C. A review of the fate of micropollutants in wastewater treatment plants. Wiley Interdiscip. Rev. Water 2015, 2, 457-487. [CrossRef] 
38. Su, Z.G.; Dai, T.J.; Tang, Y.S.; Tao, Y.; Huang, B.; Mu, Q.L.; Wen, D.H. Sediment bacterial community structures and their predicted functions implied the impacts from natural processes and anthropogenic activities in coastal area. Mar. Pollut. Bull. 2018, 131, 481-495. [CrossRef]

39. Ramirez, K.S.; Craine, J.M.; Fierer, N. Consistent effects of nitrogen amendments on soil microbial communities and processes across biomes. Glob. Change Biol. 2012, 18, 1918-1927. [CrossRef]

40. Zeng, J.; Liu, X.J.; Song, L.; Lin, X.G.; Zhang, H.Y.; Shen, C.C.; Chu, H.Y. Nitrogen fertilization directly affects soil bacterial diversity and indirectly affects bacterial community composition. Soil Biol. Biochem. 2016, 92, 41-49. [CrossRef]

41. Tripathi, B.M.; Kim, M.; Singh, D.; Lee-Cruz, L.; Lai-Hoe, A.; Ainuddin, A.; Go, R.; Rahim, R.A.; Husni, M.; Chun, J. Tropical soil bacterial communities in Malaysia: $\mathrm{pH}$ dominates in the equatorial tropics too. Microb. Ecol. 2012, 64, 474-484. [CrossRef] [PubMed]

42. Yadav, T.C.; Khardenavis, A.A.; Kapley, A. Shifts in microbial community in response to dissolved oxygen levels in activated sludge. Bioresour. Technol. 2014, 165, 257-264. [CrossRef] [PubMed]

43. Sears, K.; Alleman, J.E.; Barnard, J.L.; Oleszkiewicz, J.A. Impacts of reduced sulfur components on active and resting ammonia oxidizers. J. Ind. Microbiol. Biot. 2004, 31, 369-378. [CrossRef] [PubMed]

44. García-Armisen, T.; İnceoğlu, Ö.; Ouattara, N.K.; Anzil, A.; Verbanck, M.A.; Brion, N.; Servais, P. Seasonal variations and resilience of bacterial communities in a sewage polluted urban river. PLOS ONE 2014, 9, e92579. [CrossRef] [PubMed]

45. Wang, K.; Ye, X.S.; Chen, H.P.; Zhao, Q.F.; Hu, C.J.; He, J.Y.; Qian, Y.X.; Xiong, J.B.; Zhu, J.L.; Zhang, D.M. Bacterial biogeography in the coastal waters of northern Zhejiang, East China Sea is highly controlled by spatially structured environmental gradients. Environ. Microbiol. 2015, 17, 3898-3913. [CrossRef] [PubMed]

(C) 2019 by the authors. Licensee MDPI, Basel, Switzerland. This article is an open access article distributed under the terms and conditions of the Creative Commons Attribution (CC BY) license (http://creativecommons.org/licenses/by/4.0/). 